\title{
Rous Sarcoma Virus Positive
}

National Cancer Institute

\section{Source}

National Cancer Institute. Rous Sarcoma Virus Positive. NCI Thesaurus. Code C142092.

An indication that rous sarcoma virus has been detected in a sample. 